\title{
Chronic lymphocytic leukaemia presenting as branch retinal artery occlusion and optic disc infiltration
}

\author{
Jefferson Berryman, Ala Moshiri, Melinda Chang
}

Department of Ophthalmology, UC Davis, Sacramento, California, USA

Correspondence to Dr Melinda Chang, melinda.y.wu@gmail.com

Accepted 24 September 2018

\section{DESCRIPTION}

A previously healthy 52-year-old man presented to the emergency department with acute painless vision loss in the inferior visual field of his left eye. Review of systems was positive for daily headaches over the past 3 months but otherwise negative for neurological symptoms. Bedside examination was notable for a visual acuity of 20/40 in addition to a relative afferent pupillary defect in the left eye. Initial fundus examination revealed optic disc oedema, which appeared infiltrative, in addition to superior retinal whitening (figure 1). Subsequent fluorescein angiography showed a superior branch retinal artery occlusion (BRAO, figure 2A). Optical coherence tomography angiography confirmed superior retinal capillary non-perfusion with arteriolar narrowing at the optic disc border (figure 2B).

Initial laboratory workup in the emergency department revealed a white cell count of $62.1 \mathrm{~K}$ with $82.5 \%$ lymphocytes. Initial cerebrospinal fluid (CSF) analysis on lumbar puncture contained $70 \mathrm{mg} / \mathrm{dL}$ glucose, $39 \mathrm{mg} / \mathrm{dL}$ protein and 17 white blood cells per $\mu \mathrm{L}$ with $88 \%$ lymphocytes. The patient was admitted for a systemic workup after MRI revealed no abnormal optic nerve enhancement or thickening. A lymph node biopsy showed proliferation of small lymphocytes positive for B cell markers consistent with chronic lymphocytic leukaemia (CLL) and subsequent CSF flow cytometry revealed $84 \%$ CD19 + B cells confirming central nervous system (CNS) involvement.

The patient received four doses of intrathecal chemotherapy with methotrexate/cytarabine/hydrocortisone in addition to one cycle of fludarabine

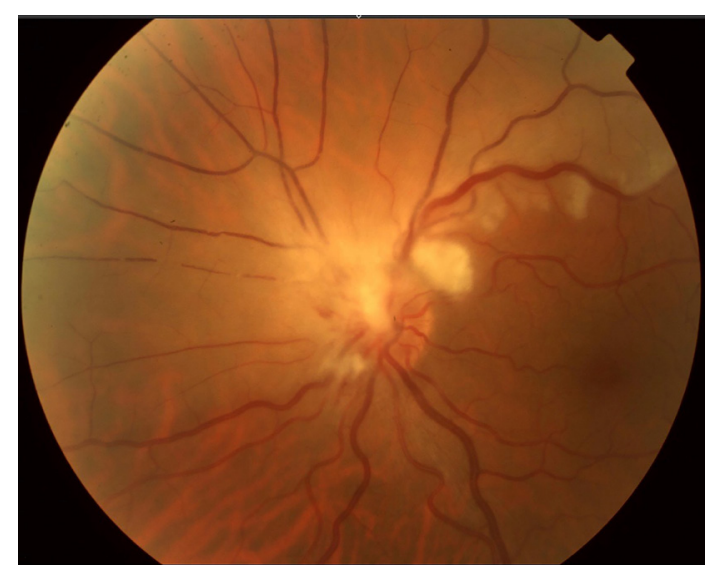

Figure 1 Fundus photograph of the left eye showing superior and nasal optic disc oedema with apparent leukaemic infiltration, peripapillary haemorrhages and superior retinal whitening.

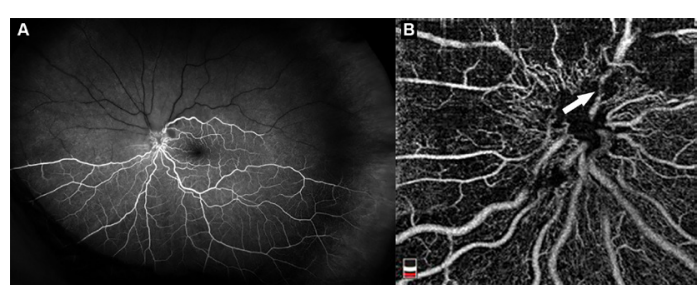

Figure 2 (A) Arteriovenous phase fluorescein angiography of the left eye showing a large superior fovea-sparing branch retinal artery occlusion. (B) Optical coherence tomography angiography demonstrating superior and nasal peripapillary capillary non-perfusion and possible flow interruption of superior retinal arteriole (arrow) at the optic disc.

and rituximab systemically. He began a course of intravenous steroids for 3 days for his vision loss with transition to oral prednisone thereafter. Three weeks after initial diagnosis, his visual acuity had improved to 20/30 with resolution of his optic disc oedema although his inferior visual field deficit remained. The patient was continued on intrathecal chemotherapy as an outpatient in addition to one dose of ibrutinib. Three months after initial diagnosis, the patient was sent to the emergency department for progressive shortness of breath and night sweats. He was admitted for broad-spectrum antibiotics and was subsequently found to have Aspergillus pneumonia. The patient ultimately developed acquired respiratory distress syndrome, acute renal failure and cerebral oedema and succumbed to his illness during this admission.

Optic nerve involvement as the initial presentation of CLL is exceptionally rare. When it occurs, it typically presents insidiously with progressive visual field loss and decreased visual acuity. ${ }^{1}$ There have been reports of optic nerve sheath biopsy to confirm the diagnosis of CLL involvement ${ }^{2}$; however, we elected to forego this given the results of CSF flow cytometry and the patient's excellent visual acuity and response to treatment. We hypothesise that oedema and leukaemic infiltration of our patient's optic nerve caused vascular compression of the superior retinal vascular arcade leading to a BRAO. An alternative explanation is that hyperviscocity may have contributed to both retinal and optic disc ischaemia, leading to BRAO and optic disc oedema. Although there have been rare case reports of optic disc infiltration with simultaneous retinal artery occlusion in acute lymphoblastic leukaemia, ${ }^{3}$ to our knowledge, this is the first report of this as a presenting sign of CLL. 


\section{Learning points}

- Optic disc oedema and infiltration in chronic lymphocytic leukaemia (CLL) are rare but can occasionally be the presenting sign of this disorder.

- Systemic workup in cases of atypical optic disc oedema and branch retinal artery occlusion can aid in the timely diagnosis of aggressive systemic disease.

- To our knowledge, this is the first case report of simultaneous optic disc oedema and branch retinal artery occlusion as the initial presentation of CLL.

Contributors All authors (JB, AM and $\mathrm{MC}$ ) were involved in conception and design of the report. JB and $\mathrm{MC}$ were responsible for drafting the manuscript. All authors (JB, AM and MC) approved the final version.

Funding The authors have not declared a specific grant for this research from any funding agency in the public, commercial or not-for-profit sectors.

Competing interests None declared.

Patient consent Next of kin obtained.

Provenance and peer review Not commissioned; externally peer reviewed.

\section{REFERENCES}

1 Currie JN, Lessell S, Lessell IM, et al. Optic neuropathy in chronic lymphocytic leukemia. Arch Ophthalmol 1988;106:654-60.

2 Khan K, Malik Al, Almarzouqi SJ, et al. Optic neuropathy due to chronic lymphocytic leukemia proven with optic nerve sheath biopsy. J Neuroophthalmol 2016;36:61-6.

3 Moisseiev E, Ling J, Morse LS. Leukemic optic nerve infiltration complicated by retinal artery and vein occlusions. Retina 2017:37:e10.

Copyright 2018 BMJ Publishing Group. All rights reserved. For permission to reuse any of this content visit http://group.bmj.com/group/rights-licensing/permissions.

BMJ Case Report Fellows may re-use this article for personal use and teaching without any further permission.

Become a Fellow of BMJ Case Reports today and you can:

- Submit as many cases as you like

- Enjoy fast sympathetic peer review and rapid publication of accepted articles

- Access all the published articles

- Re-use any of the published material for personal use and teaching without further permission

For information on Institutional Fellowships contact consortiasales@bmjgroup.com

Visit casereports.bmj.com for more articles like this and to become a Fellow 